\title{
SHORT-TERM EFFECTS OF NATURAL STREAM DISCHARGE ON THE WATER QUALITY TRENDS ALONG TWO SMALL URBAN STREAMS - A PILOT STUDY
}

\section{Nina Haas ${ }^{1}$, Mateusz Werner ${ }^{2}$ \& Mirela Sertić Perić ${ }^{3 *}$}

${ }^{1}$ Faculty of Science, University of Salzburg, Hellbrunnerstrasse 34, 5020 Salzburg, Austria

(E-mail: nina.haas97@gmail.com)

${ }^{2}$ Faculty of Mechanical and Power Engineering, Wroclaw University of Science and Technology, Wybrzeże Wyspiańskiego Street 27, 50-370 Wrocław, Poland (E-mail: mateusz.werner95@gmail.com)

${ }^{3}$ Department of Biology, Faculty of Science, University of Zagreb, Rooseveltov trg 6, 10000 Zagreb, Croatia

(E-mail: msertic@biol.pmf.hr), Phone: +385 14877 705, https://orcid.org/0000-0002-4744-7884

Haas, N., Werner, M. \& Sertić Perić, M.: Short-term effects of natural stream discharge on the water quality trends along two small urban streams - a pilot study. Nat. Croat., Vol. 28, No. 2., 289-303, 2019, Zagreb.

In this pilot-study, we investigated the short-term effects of natural stream discharge on the stream water quality at six sites located along the two urban streams - Bliznec (B) and Veliki potok (VP) - flowing through Zagreb, capital of Croatia. The streams source within the Medvednica Nature Park (upper stream reaches) and flow along an increasing urban gradient in central Zagreb region (middle and lower stream reaches). The following physico-chemical parameters were measured every other day over the two-week period in October 2017: stream discharge, water temperature and oxygen concentration, conductivity, $\mathrm{pH}$, chemical oxygen demand $\left(\mathrm{COD}_{\mathrm{KMnO} 4}\right)$, and in-stream concentrations of nutrients (nitrites, nitrates, orthophosphates). Nutrients were the most variable parameters during the two-week period. Bliznec generally showed significantly higher discharge and oxygen levels compared to Veliki potok, which had significantly higher $\mathrm{COD}_{\mathrm{KMnO4}}$ and nitrite concentrations. Middle and lower stream reaches had significantly higher temperature, nitrite and nitrate concentrations in comparison to the upper reaches. Several physico-chemical parameters (discharge, nitrites, nitrates, orthophosphates, conductivity and $\mathrm{COD}_{\mathrm{KMnO44}}$ ) evidenced to be highly synchronized between the two streams, among the three stream reaches and among the six sites over time, which was corroborated by relatively high proxy for temporal concordance $(\tau>0.60)$ of these parameters. This indicated that environmental conditions (stream water quality) synchronously vary across space and over time along our study streams. The data also revealed significant between-site and temporal changes of the physico-chemical parameters after a major storm event. Moreover, conductivity was found to correlate with discharge. Findings of the present pilot study indicate that urban streams are very dynamic ecosystems showing an increased sensitivity to environmental changes, such as anthropogenic influences and local weather conditions. We suggest that the extensive environmental variability of urban streams should be considered in the scope of ecological studies and environmental management approaches within urban zones.

Keywords: urban streams, anthropogenic influence, land use, water quality

Haas, N., Werner, M. \& Sertić Perić, M.: Kratkoročni učinci prirodnog protoka na kvalitetu vode duž dva urbana potoka - pilot-istraživanje. Nat. Croat., Vol. 28, No. 2., 289-303, 2019, Zagreb.

U ovom pilot-istraživanju istražili smo kratkoročne učinke prirodnog protoka na kakvoću vode na šest postaja smještenih duž dva urbana potoka - Blizneca (B) i Velikog potoka (VP) - koji protječu kroz Zagreb, glavni grad Hrvatske. Potoci izviru unutar Parka prirode Medvednica

\footnotetext{
* corresponding author
} 
(gornji tok) i teku duž rastućeg urbanog gradijenta, kroz središnji dio Zagreba (srednji i donji tok). Svaki drugi dan tijekom dva tjedna u listopadu 2017. mjereni su sljedeći fizičko-kemijski parametri za vodu: protok, temperatura vode i koncentracija kisika, konduktivitet, $\mathrm{pH}$, kemijska potrošnja kisika $\left(\mathrm{KPK}_{\mathrm{KMnO4}}\right)$ i koncentracija hranjivih soli (nitrita, nitrata, ortofosfata) u vodi. Najvarijabilniji parametri tijekom dva tjedna bile su koncentracije hranjivih soli. Bliznec je općenito pokazao značajno više vrijednosti protoka i koncentracije kisika u odnosu na Veliki potok, koji je imao značajno više vrijednosti $\mathrm{KPK}_{\mathrm{KMnO4}}$ i koncentracije nitrita. Srednji i donji dijelovi toka oba potoka imali su značajno više temperature te koncentracije nitrita i nitrata u odnosu na gornji tok. Nekoliko fizičko-kemijskih parametara (protok, koncentracije nitrita, nitrata i ortofosfata, konduktivitet i $\mathrm{KPK}_{\mathrm{KMnO4}}$ ) pokazali su veliku podudarnost vremenskih trendova između dva potoka, između tri dijela toka i između šest postaja, što je i dokazano relativno visokim koeficijentom $(\tau>0.60)$ koji ukazuje na vremensko podudaranje parametara. To je nadalje ukazalo da se okolišni uvjeti (kakvoća vode) duž naših potoka ujednačeno mijenjaju u prostoru i vremenu. Podaci su također ukazali na značajne promjene mjerenih fizikalno-kemijskih parametara nakon nevremena (razdoblja povišenog protoka vode). Nadalje, korelacijskom analizom je utvrđeno da konduktivitet značajno ovisi o protoku. Rezultati ovog pilot-istraživanja pokazuju da su urbani potoci vrlo dinamični ekosustavi koji pokazuju povećanu osjetljivost na promjene u okolišu, kao što su antropogeni utjecaji i lokalni vremenski uvjeti. Predlažemo da se u okviru ekoloških studija i pri upravljanju okolišem unutar urbanih zona uzme u obzir značajna ekološka varijabilnost urbanih vodotoka.

Ključne riječi: urbani potoci, antropogeni utjecaj, uporaba zemljišta, kvaliteta vode

\section{INTRODUCTION}

Anthropogenic and environmental disturbances associated to urbanization often modify stream morphology, which then further affects physical (discharge), chemical (water quality) and biological (biota) status of urban streams (PRICE et al., 2019). The composition of the (urban) streams' riparian zone significantly influences the water quality as well (Mello et al., 2018). While forest cover primarily improves the water quality and filters pollutants (S. Ding et al., 2013), urban regions accumulate pollutants on impervious surfaces contributing to the impending water degradation (LeE et al., 2009; J. Ding et al., 2016). The surface water quality is furthermore impacted by the local weather conditions (BHURTUN et al., 2019)". For example, big storm (i.e., heavy precipitation) events may cause increased nutrient release from a major urban area into the associated streams, which may further yield far-reaching indirect effects on biogeochemical cycles and biodiversity trends along urban streams (e.g., Grimm et al., 2005; OLDs et al., 2018). This is particularly important for small urban streams (characterized by small sizes and high degree of imperviousness), which exhibit a faster and stronger stream discharge response (CHEN \& CHANG, 2014; YANG et al., 2016). On the other hand, small streams efficiently retain (i.e., uptake) and transform nutrients (i.e., nitrogen and phosphorus compounds), which can be important in regulating downstream nutrient fluxes (PETERson et al., 2001). Thus, small urban streams may show high fluctuations in water parameters (especially nutrients) with changes in weather conditions, leading to fast changing environment within these streams. The extreme environmental variations may further affect spatiotemporal dynamics of water quality, biodiversity and energy flow (i.e., food web) trends along streams within urban zones (HASEnmueller et al., 2017; Price et al., 2019). 
Many previous studies have shown demonstrable effects of natural stream flow (i.e., discharge) and artificial flood pulses on the urban stream water chemistry, physical habitat and riparian conditions, and on the urban stream biota and ecological functioning of urban streams (Konrad \& BooTH, 2005; Pyron \& Neumann, 2008; Walsh et al., 2012; Coleman II et al., 2011; Lizotte et al., 2012). However, few studies have investigated the short-term effects of natural stream flows on the water quality trends and nutrient (i.e., nitrogen, phosphorus) pulses within urban streams (Rörig et al., 2007; FLEMING, 2007). Water chemistry and nutrient trends before, during and upon natural stream flow pulses within urban streams can reveal important information on the effects of anthropogenic and environmental disturbances on the ecological status of these streams. Moreover, an insight into urban stream dynamics can help us develop appropriate environmental management strategies within urban zones.

Within the present pilot-study, we investigated the short-term effects of natural stream discharge on the water quality, including nutrient (i.e., nitrite, nitrate, orthophosphate) concentrations, along two small urban streams flowing through Zagreb, capital of Croatia. During a two-week period, in two-day intervals, we measured discharge and water quality proxies (i.e., water temperature, oxygen concentration, conductivity, $\mathrm{pH}$, chemical oxygen demand - $\mathrm{COD}_{\mathrm{KMnO}^{\prime}}$ and instream concentrations of nutrients - nitrites, nitrates and orthophosphates) within the upper (upstream), middle and lower (downstream) stream reaches differing in the surrounding land use type and intensity (i.e., anthropogenic activity). The upper stream reaches are located in forest-covered areas (i.e., within the Nature Park zone), while the lower reaches flow through an increasing urban gradient within Zagreb. We generally hypothesize that the middle and lower stream reaches (within the urban zone) accumulate higher nutrient concentrations than the upper reaches (within the woodland zone). We further predict that the measured water quality parameters greatly vary with the discharge, expecting lower conductivity (i.e., dilution of stream water), but higher nutrient (i.e., nitrite, nitrate and orthophosphate) inflow during higher natural stream discharge (i.e., eventual high precipitation) events.

\section{MATERIALS AND METHODS}

\section{Study sites}

Stream discharge and water quality parameters were measured along two small streams flowing through Zagreb, Croatia - Bliznec (B) and Veliki potok (VP) - (Fig. 1). Zagreb is the largest city in Croatia, in terms of population (792,875 according to the 2011 Croatian census) (World Population Review, 2018) and the center of economy and municipals of the country (PRICE et al., 2019). The research was conducted at six study sites stretched along the two streams. The reference sites (B1, VP1) were located in the upper stream reaches within the Medvednica Nature Park (considered as an area of low anthropogenic influence). Other sites were aligned along an increasing urban gradient within Zagreb - sites B2 and VP2 were located in the middle, and B3 and VP3 in the lower stream reaches (Fig. 1). 


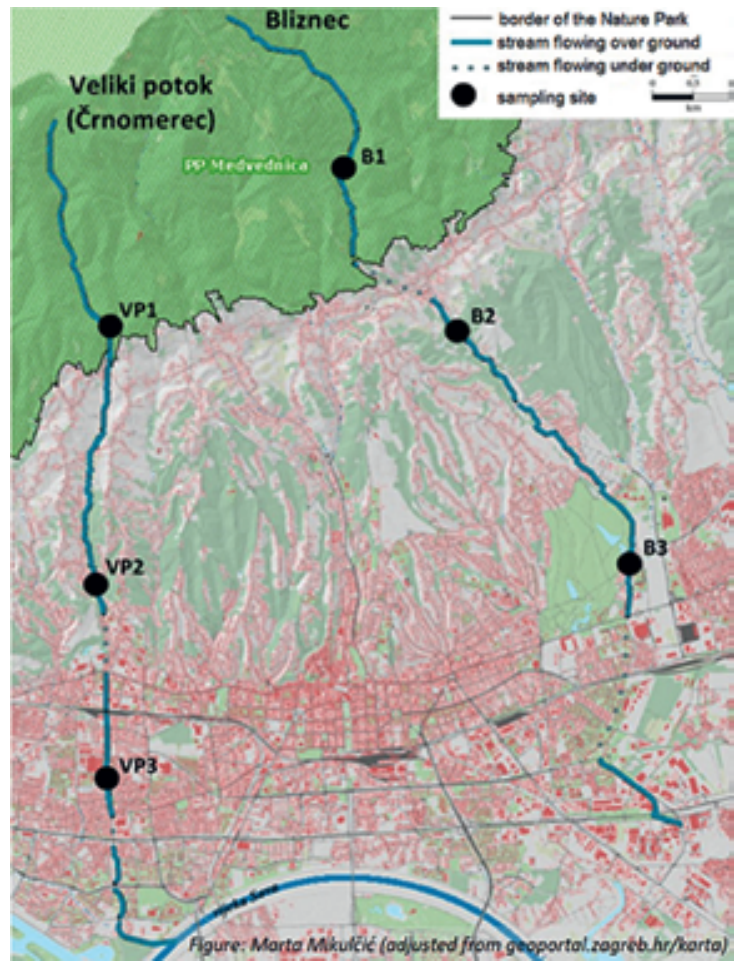

Fig. 1. Study sites at the two urban streams Bliznec and Veliki potok (adjusted from Mikulčić, 2017).

\section{Physico-chemical parameters}

Over a two-week period in October 2017 (October $2^{\text {nd }}$-October $13^{\text {th }}$ ), the following physico-chemical parameters were measured in a two-days interval (SERTIĆ Perić et al., 2011): water temperature, oxygen concentration, conductivity, $\mathrm{pH}$, chemical oxygen demand - $\mathrm{COD}_{\mathrm{KMnO}^{\prime}}$ and in-stream concentrations of nutrients - nitrites, nitrates and orthophosphates. Several parameters (water temperature, oxygen concentration, conductivity, $\mathrm{pH}$ ) were measured using the respective portable field meters. Before each sampling occasion, the probes were calibrated. The water temperature $(t)$ and dissolved oxygen concentration $(\mathrm{DO})$ were measured by using oximeter (OXI 96, WTW GmbH, Weilheim, Germany), pH by pH-meter (330i, WTW GmbH, Weilheim, Germany) and conductivity (Cond) by conductivity meter (Hach SensIon 5, Hach Lange GmbH, Düsseldorf, Germany). For the subsequent water analysis in the laboratory, an additional $1 \mathrm{~L}$ water sample was collected and stored at $4^{\circ} \mathrm{C}$. Within $24 \mathrm{~h}$, the concentrations of nitrite $\left({\mathrm{N}-\mathrm{NO}_{2}}^{-}\right)$, nitrate $\left(\mathrm{N}^{-\mathrm{NO}_{3}}{ }^{-}\right)$ and orthophosphate ( $\left.\mathrm{P}^{-} \mathrm{PO}_{4}{ }^{3-}\right)$ were spectrophotometrically evaluated, following the standard methods of APHA (1985). Diazotization method (using sulfanilic acid and 1-naphthylamine) was applied for determination of nitrites, sodium salicylate method for nitrates, and molybdenum blue phosphorus method for orthophosphates (APHA, 1985). The nitrite ion concentration was determined by measuring the absorbance of the azo color at $\lambda=520 \mathrm{~nm}$; nitrate ion concentration 
by measuring the absorbance of the yellow nitrosalicylic acid complex at $\lambda=420$ $\mathrm{nm}$; and orthophosphate ion concentration by absorbance measurement of the molybdenum blue complex at $\lambda=690 \mathrm{~nm}$. Respective reagent blanks were used as reference solutions for each ion (nitrite, nitrate, orthophosphate) to measure the absorbance of each sample. For the determination of the concentration of each ion, the calibration curves coupled with the absorbance readings of each sample were used. The reference solutions were made for each ion from a series of eight standard solutions within the expected nitrite, nitrate and orthophosphate ranges $\left(0.001-0.1 \mathrm{~N}-\mathrm{NO}_{2} / \mathrm{mgL}^{-1} ; 0.05-1 \mathrm{~N}-\mathrm{NO}_{3} / \mathrm{mg} \mathrm{L}^{-1}, 0.01-0.15 \mathrm{P}^{-\mathrm{PO}_{4}^{3-}} / \mathrm{mg}\right.$ $\mathrm{L}^{-1}$ ). Standardized acidic potassium permanganate trimetric method (Deutsches Institut FÜr Normung, 1986) was used to measure the total chemical oxygen demand $\left(\mathrm{COD}_{\mathrm{KMnO}}\right)$. Water discharge was measured as described in DAvis et al. (2001). For the estimate of total discharge, the stream width, average depth (three measurements at regular intervals along a lateral transect of the stream) and flow velocity (flow velocity meter P600, Dostman electronic GmbH) were measured. Daily observed precipitation records during the study period (Fig. 2) for Zagreb (Zagreb Maksimir rain gauge station) were extracted from the Croatian Meteorological and Hydrological Service (DHMZ) data available online (https:// meteo.hr/klima_e.php?section=klima_pracenje\&param=klel\&Grad=zagreb_ maksimir\&Mjesec=12\&Godina=2017).

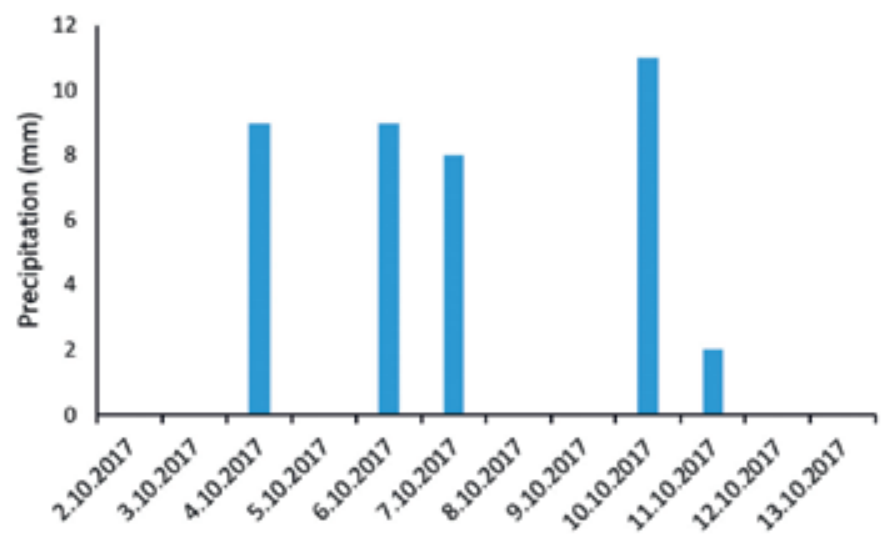

Fig. 2. Precipitation records during the study period at Zagreb Maksimir rain gauge station (extracted from the Croatian Meteorological and Hydrological Service (DHMZ) data available online at: https://meteo.hr/klima_e.php? section=klima_pracenje\&param=klel\&Grad=zagreb_ maksimir\&Mjesec=12\&Godina=2017).

\section{Statistical analysis}

Discharge and physico-chemical water parameters recorded at each site, within each stream and stream reach, were summarized as mean values, standard deviations (SD) and coefficients of variation (CV). Several statistical analyses were performed using Statistica 9.1 (STATSoft, INC., 2010). To test significant differences of the parameters between the sites and stream reaches, Kruskal-Wallis (K-W test) 
ANOVA by ranks (followed by multiple comparison post hoc test) was used. MannWhitney U-Test (M-W test) was used to test the differences of the parameters between the two streams. We applied Spearman's rank correlation analysis to determine the relationship (Spearman correlation coefficients, $R$ ) between discharge and other measured parameters. The Friedman's ANOVA (a nonparametric alternative of one-way repeated measures ANOVA) and calculation of Kendall's coefficient of concordance $(\tau)$ were applied to investigate temporal differences between sites, stream reaches and individual streams. Thereby, $\chi^{2}$ statistics and accompanying $p$-values in the Friedman's ANOVA show significant temporal differences between sampling occasions common to the two streams and/or stream reaches and/or six sampling sites, whereas $\tau$ quantifies the temporal concordance of each variable between the two streams and/or stream reaches and/or six sampling sites ( $\tau=1$ indicates complete concordance; $\tau=0$ indicates no concordance). Temporal differences shown significant by Friedman's ANOVA were additionally tested by a nonparametric Kruskal-Wallis (K-W) test and respective multiple comparison post hoc procedure. For these K-W tests, we compared the sampling date means of the measured parameters for each stream, stream reach and site to test if the overall temporal differences shown significant by Friedman's ANOVA were sourcing from the differences between the individual dates. Differences within all tests were considered statistically significant when $p<0.05$.

\section{RESULTS}

\section{Streams}

Between the two streams, significant differences were observed for discharge, $\mathrm{COD}_{\mathrm{KMnO4}}$, and dissolved oxygen and nitrite concentrations. In general, VP showed significantly higher concentrations of nitrites $(\mathrm{M}-\mathrm{W}$ test: $p<0.05)$ and $\mathrm{COD}_{\mathrm{KMnO4}}$ (M-W test: $p<0.01$ ) compared to $\mathrm{B}$, which had significantly higher discharge (M-W test: $p<0.0001)$ and dissolved oxygen levels (M-W test: $p<0.05)$ (Fig. 3).

No significant temporal differences (i.e., differences among the sampling dates) of the measured parameters between and within the two streams were observed, as the Friedman's ANOVA $p$-value was higher than 0.05 for all measured parameters. However, $\tau$-values evidenced relatively high temporal concordance of most variables between the two streams ( $\mathrm{pH}: \tau=0.63 ; \mathrm{N}^{-\mathrm{NO}_{3}}: \tau=0.66 ; \mathrm{N}^{-} \mathrm{NO}_{2}^{-}$: $\tau=0.71 ; \mathrm{P}^{-\mathrm{PO}_{4}}{ }^{3-}: \tau=0.83$; Cond, $\mathrm{Q}$ and $\mathrm{COD}_{\mathrm{KMnO} 4}: \tau=0.89$; water temperature: $\tau=$ 0.91). Only dissolved oxygen concentrations showed less harmonized temporal trend between the two streams, evidenced by lower $\tau$-value $(\tau=0.23)$ (Fig. 3).

\section{Stream reaches}

Water temperature, and nitrite and nitrate concentrations were the only parameters yielding significant differences between the three (upper, middle, lower) stream reaches (Fig. 4). Lower stream reaches in the urban regions showed significantly higher water temperature $(\mathrm{K}-\mathrm{W}$ test: $\mathrm{H}(2, \mathrm{~N}=36)=8.37, p<0.05)$ and $\mathrm{N}_{-} \mathrm{NO}_{2}{ }^{-}$concentrations ( $\mathrm{K}-\mathrm{W}$ test: $\left.\mathrm{H}(2, \mathrm{~N}=34)=6.10, p<0.05\right)$ in comparison to the upper reaches, whereas middle stream reaches showed significantly higher $\mathrm{N}-\mathrm{NO}_{3}{ }^{-}$concentrations $(\mathrm{K}-\mathrm{W}$ test: $\mathrm{H}(2, \mathrm{~N}=34)=16.42, p<0.001)$. 

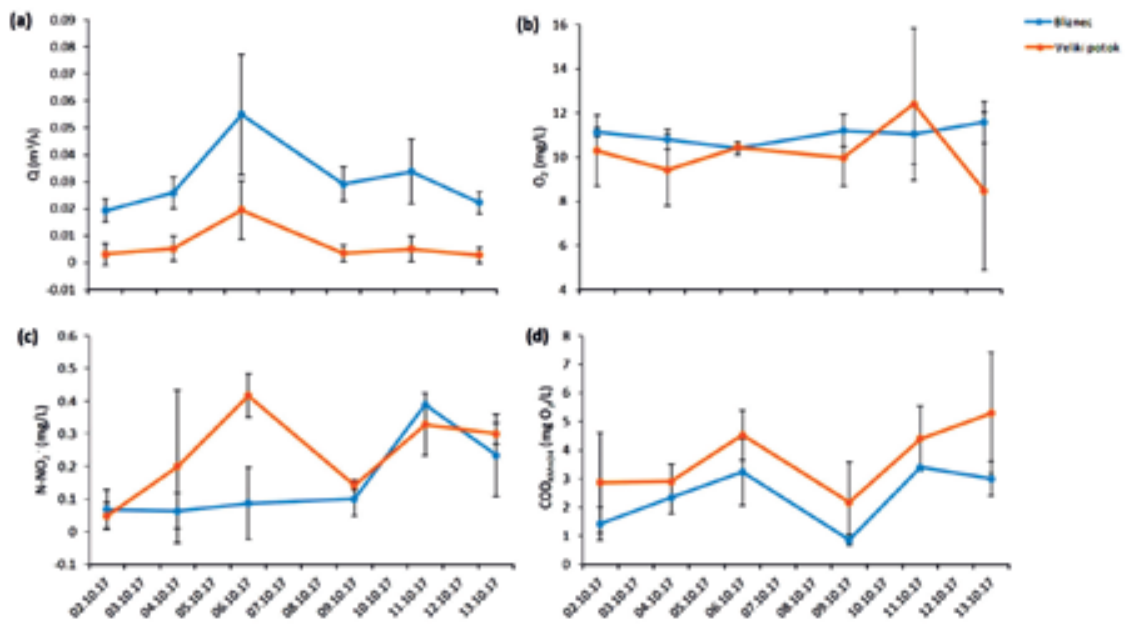

Fig. 3. Mean ( \pm SD) discharge (a), dissolved oxygen (b) and nitrite (c) concentrations, and chemical oxygen demand (d) at the two study streams (Bliznec, Veliki potok) during the study period.
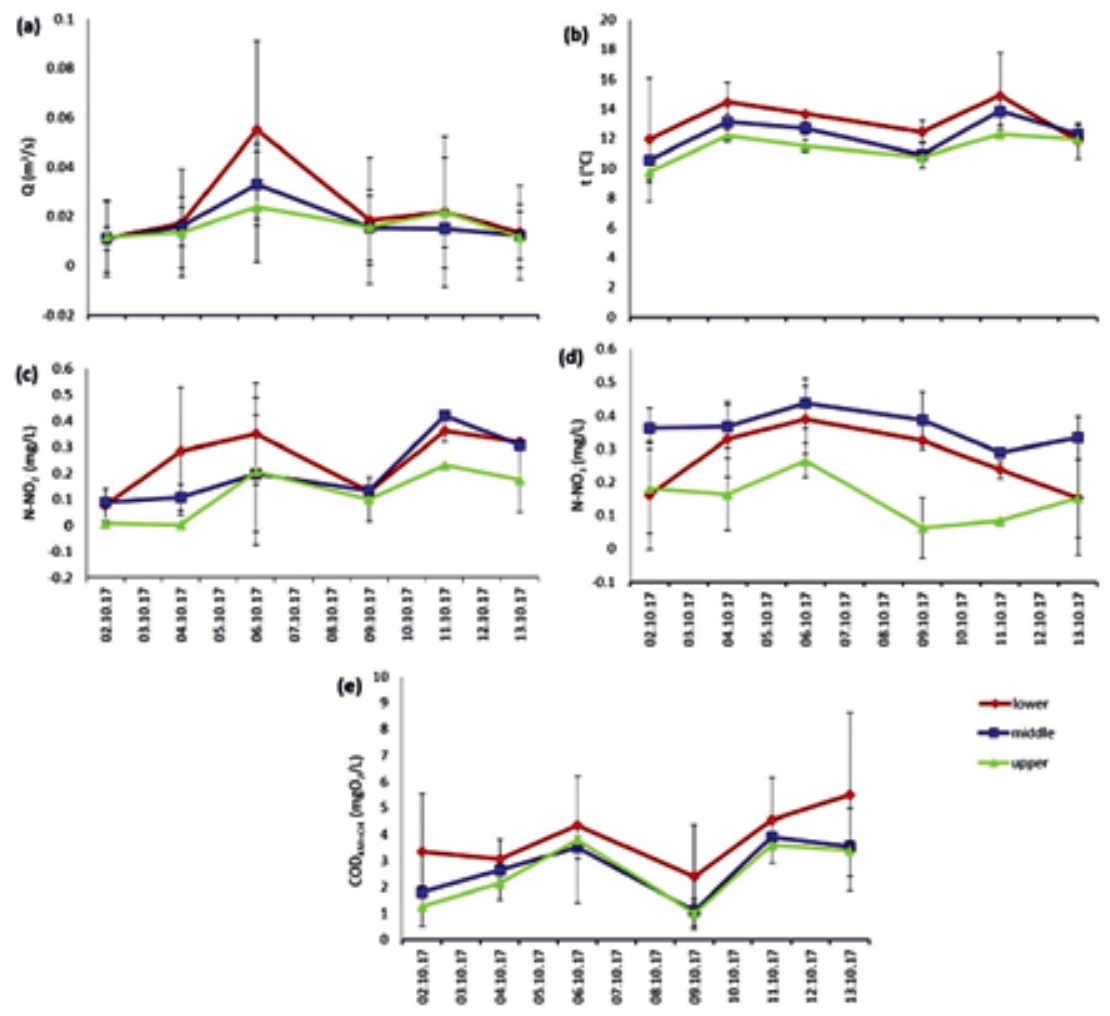

Fig. 4. Mean $( \pm S D)$ discharge (a), water temperature (b), nitrite (c) and nitrate (d) concentrations, and chemical oxygen demand (e) within lower, middle and upper stream reaches of the two study streams during the study period. 
Discharge within the different stream reaches showed significant temporal differences (Friedman's ANOVA: $\left.\chi^{2}(\mathrm{~N}=3, \mathrm{df}=5)=13.48, p<0.05\right)$ associated to significantly different discharge measurements between $2^{\text {nd }}$ and the $6^{\text {th }}$ of October (K-W test: $\mathrm{H}(5, \mathrm{~N}=18)=14.98, p<0.05)$ (Fig. 4). $\mathrm{COD}_{\mathrm{KMnO} 4}$ (Friedman's ANOVA: $\chi^{2}$ $(\mathrm{N}=3, \mathrm{df}=5)=13.10, p<0.05)$ and $\mathrm{N}^{-N_{2}}{ }_{2}^{-}$concentration (Friedman's ANOVA: $\chi^{2}$ $(\mathrm{N}=3, \mathrm{df}=5)=13.67, p<0.05)$ also yielded significant temporal differences among the stream reaches, but accompanying $\mathrm{K}-\mathrm{W}$ and multiple comparison post-hoc tests showed the borderline significance with $p$ value of 0.05 , differentiating October $9^{\text {th }}$ vs. October $11^{\text {th }}$ (for $\mathrm{COD}_{\mathrm{KMnO}}$ ), and October $2^{\text {nd }}$ vs. October $11^{\text {th }}$ (for $\mathrm{N}-\mathrm{NO}_{2}{ }^{-}$concentrations) (Fig. 4).

Similarly to between-stream comparison, $\tau$-values evidenced relatively high temporal concordance of most variables between the three stream reaches $(\mathrm{P}$ $\mathrm{PO}_{4}^{3-}: \tau=0.61 ; \mathrm{N}^{3-N_{3}}: \tau=0.66 ; \mathrm{pH}: \tau=0.67$; Cond: $\tau=0.71 ; \mathrm{COD}_{\mathrm{KMnO} 4}$ and water temperature: $\tau=0.87$; $\mathrm{Q}: \tau=0.90 ; \mathrm{N}-\mathrm{NO}_{2}: \tau=0.91$ ) (see Fig. 4 for the parameters yielding significant temporal differences). Only dissolved oxygen concentrations showed less harmonized temporal trend between the three stream reaches, evidenced by lower $\tau$-value $(\tau=0.31)$.

Sites

Conductivity, $\mathrm{COD}_{\mathrm{KMnO}_{4}} \mathrm{~N}-\mathrm{NO}_{2}{ }_{2}, \mathrm{~N}-\mathrm{NO}_{3}{ }_{3}^{-}$and Q showed significant between-site differences. Site B1 (Cond $=366 \pm 17 \mu \mathrm{S} / \mathrm{cm}$ ) had significantly lower conductivity than sites B3 (Cond $=450 \pm 44 \mu \mathrm{S} / \mathrm{cm})$ and VP2 (Cond $=490 \pm 76 \mu \mathrm{S} / \mathrm{cm})(\mathrm{K}-\mathrm{W}$ test: $\mathrm{H}(5, \mathrm{~N}=36)=13.30, p<0.05)$ (Fig. 5). Compared to VP3 $\left(\mathrm{COD}_{\mathrm{KMnO4}}=5.00 \pm 1.53 \mathrm{mg}\right.$ $\left.\mathrm{O}_{2} / \mathrm{L}\right)$, site $\mathrm{B} 1\left(\mathrm{COD}_{\mathrm{KMnO4}}=1.50 \pm 0.76 \mathrm{mg} \mathrm{O}_{2} / \mathrm{L}\right)$ had significantly lower $\mathrm{COD}_{\mathrm{KMnO4}}$ ( $\mathrm{K}-\mathrm{W}$ test: $\mathrm{H}(5, \mathrm{~N}=34)=14.73, p<0.05)$. The same significant between-site trend $(\mathrm{K}-\mathrm{W}$ test: $\mathrm{H}(5, \mathrm{~N}=34)=12.53, p<0.05)$ was observed for $\mathrm{N}-\mathrm{NO}_{2}{ }^{-}$concentrations $(0.296 \pm 0.178 \mathrm{mg} / \mathrm{L}$ at VP3 vs. $0.0292 \pm 0.0362 \mathrm{mg} / \mathrm{L}$ at B1) (Fig. $5 \mathrm{~b})$. With 4-fold lower $\mathrm{N}_{-\mathrm{NO}_{3}}^{-}$concentrations $(0.113 \pm 0.060 \mathrm{mg} / \mathrm{L})$, site VP1 significantly differed (K-W test: $\mathrm{H}(5, \mathrm{~N}=34)=18.00, p<0.01)$ from site VP2, where we recorded $0.404 \pm$ $0.068 \mathrm{mg} \mathrm{N}-\mathrm{NO}_{3}-/ \mathrm{L}$ during the study period. Discharge was the highest at $\mathrm{B} 3(\mathrm{Q}$ $=0.040 \pm 0.021 \mathrm{~m}^{3} / \mathrm{s}$ ), which significantly differed from VP1 and VP3, where 10fold lower discharges in comparison to B3 were recorded $\left(\mathrm{Q}=0.004 \pm 0.002 \mathrm{~m}^{3} / \mathrm{s}\right.$ at VP1, and $0.005 \pm 0.002 \mathrm{~m}^{3} / \mathrm{s}$ at VP3) (K-W test: $\left.\mathrm{H}(5, \mathrm{~N}=36)=24.80, p<0.001\right)$.

The only two parameters yielding statistically significant temporal differences among the six sites were conductivity (Friedman's ANOVA: $\chi^{2}(\mathrm{~N}=6, \mathrm{df}=5)=$

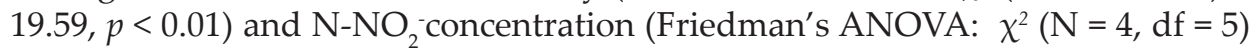
$=13.42, p<0.05$ ) (Fig. 5). According to the additional $\mathrm{K}-\mathrm{W}$ and the respective post hoc tests, conductivity was significantly lower on the date of heavy rain (October

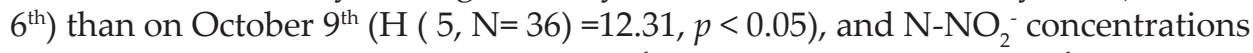
were significantly lower on October $2^{\text {nd }}$ compared to October $11^{\text {th }}(\mathrm{K}-\mathrm{W}$ test: $\mathrm{H}(5, \mathrm{~N}=34)=13.43, p<0.05)$ (Fig. 5). Friedman's ANOVA indicated temporal differences in water temperature $\left(\chi^{2}(\mathrm{~N}=6, \mathrm{df}=5)=19.11, p<0.01\right)$ and $\mathrm{COD}_{\mathrm{KMnO4}}$ $\left(\chi^{2}(\mathrm{~N}=4, \mathrm{df}=5)=15.00, p<0.05\right)$, but additional $\mathrm{K}-\mathrm{W}$ and post hoc tests proved only borderline differences $(p=0.05)$ between October $2^{\text {nd }}$ and October $11^{\text {th }}$ (for water temperature), and October $6^{\text {th }}$ and October $9^{\text {th }}$ (for $\mathrm{COD}_{\mathrm{KMnO} 4}$ ). Average water temperature on October $2^{\text {nd }}$ was $10.1 \pm 2.2^{\circ} \mathrm{C}$, while on October $11^{\text {th }}$ we measured $13.7 \pm 1.8^{\circ} \mathrm{C}$. On October $6^{\text {th }}$ (one of the heavy rain events; Fig. 2), we 
recorded $3.88 \pm 1.16 \mathrm{mg} \mathrm{O}_{2} / \mathrm{L}$ for $\mathrm{COD}_{\mathrm{KMnO}_{4}}$, whereas on October $9^{\text {th }}$ (a day without rain), the average was 2 -fold lower $\left(1.51 \pm 1.16 \mathrm{mg} \mathrm{O}_{2} / \mathrm{L}\right)$.

The $\tau$-values evidenced relatively high temporal concordance of most variables between the six sites (Cond and $\mathrm{P}_{-} \mathrm{PO}_{4}{ }^{3-}: \tau=0.65 ; \mathrm{N}^{-\mathrm{NO}_{2}}: \tau=0.67 ; \mathrm{Q}: \tau=0.71 ; \mathrm{N}^{-} \mathrm{NO}_{3}{ }^{-}$: $\left.\tau=0.74 ; \mathrm{COD}_{\mathrm{KMnO} 4}: \tau=0.75\right)$. Only $\mathrm{pH}(\tau=0.38)$ and dissolved oxygen concentrations $(\tau=0.31)$ showed less harmonized temporal trend between the six sites.

Fig. 6 shows that nutrients and $\mathrm{COD}_{\mathrm{KMnO} 4}$ were the most variable parameters during the two week period $\left(\mathrm{CV}\left(\mathrm{N}_{-} \mathrm{NO}_{2}^{-}\right)=77 \pm 22 \%\right.$; $\mathrm{CV}\left(\mathrm{P}_{-} \mathrm{PO}_{4}{ }^{3-}\right)=50 \pm 11 \%$; $\left.\mathrm{CV}\left(\mathrm{COD}_{\mathrm{KMnO} 4}\right)=43 \pm 7 \% ; \mathrm{CV}\left(\mathrm{N}_{-} \mathrm{NO}_{3}^{-}\right)=37 \pm 27 \%\right)$. The only parameter found to significantly (negatively) correlate with discharge was conductivity $(R=-0.4007, p$ $<0.05)$.
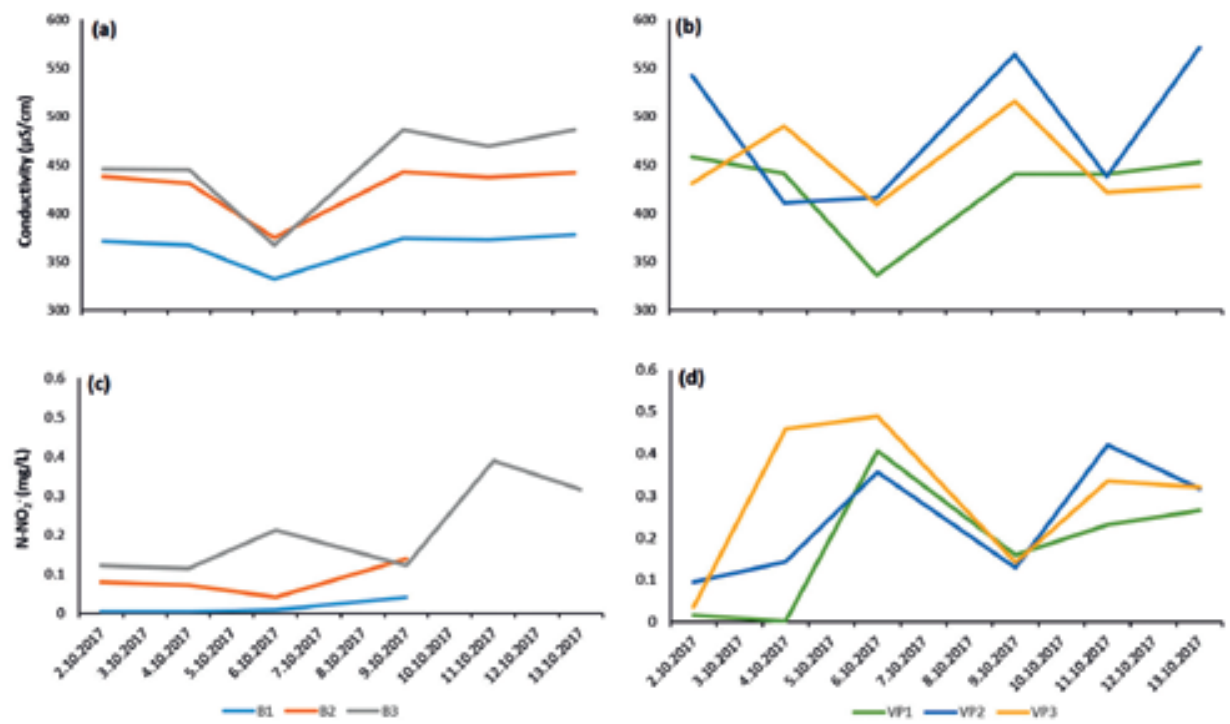

Fig. 5. Conductivity (a, b) and nitrite concentrations (c, d) measured at each site within the two study streams during the study period. These were the only two parameters yielding statistically significant temporal differences among the six sites. The codes of the study streams and sites are given in Materials and methods.
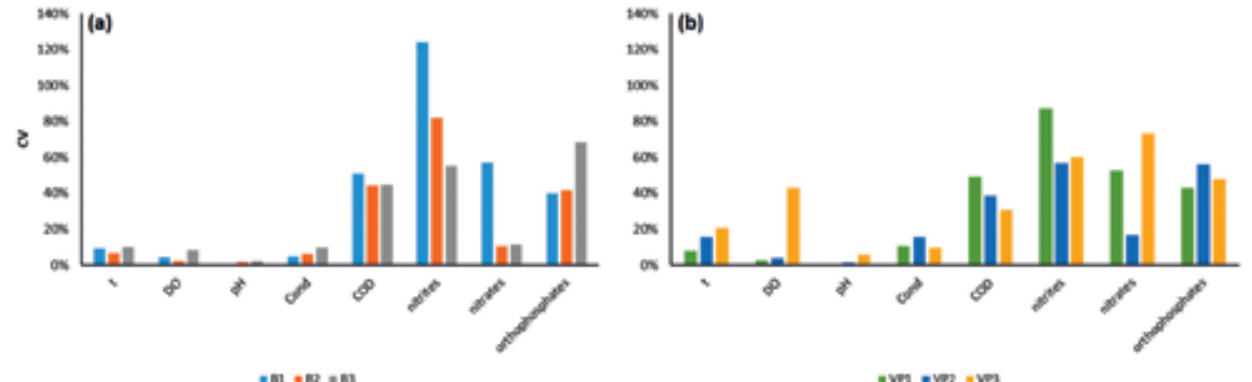

Fig. 6. Coefficients of variation (CV) of the water quality parameters measured at each site within the two study streams - Bliznec (a) and Veliki potok (b) - during the study period. CV is the ratio of the standard deviation to the mean showing the extent of variability in relation to the overall mean of the measured parameters during the study period. Study site and parameter codes aligned along the $\mathrm{x}$-axis are given in Materials and methods. 


\section{DISCUSSION}

\section{Streams and sites}

Nitrite concentrations, $\mathrm{COD}_{\mathrm{KMnO} 4^{\prime}}$ oxygen levels and discharge showed significant differences between the two streams. The differences in discharge can be explained by the differing width of the two streams and high precipitation (i.e., heavy rain) events. Bliznec has a wider channel (i.e., higher width-depth ratio) than Veliki potok, and it was therefore expected to yield higher discharge measurements (cf. FAHNESTOCK, 1968). The discharge peaks within both streams likely display the effects of two consecutive storm events (October $4^{\text {th }}$ and $6^{\text {th }}$; Fig. 2). However, the discharge differences could also be greatly affected by a dynamic interaction between urban stream flow and groundwater inputs, surrounding soil drainage and/or differences in drainage area (cf. SCHALler \& FAN, 2009). Thus, whereas Veliki potok has no major tributaries along our study reach, the discharge of Bliznec is likely greatly affected (i.e., increased) by the inflow of another relatively large urban stream Štefanovec, which confluences Bliznec $20 \mathrm{~m}$ downstream of our study site B3 (HAAs et al., personal observation from the field). The discharge further likely affected the in-stream spatio-temporal trends of oxygen, nitrite and $\mathrm{COD}_{\mathrm{KMnO4}}(\mathrm{LIETZ}, 1999)$, although there were no significant correlations between discharge and those parameters. Significant impacts of storm events on nutrient loads in streams were also reported in other studies (BHuRtun et al., 2019; Lloyd et al., 2016). Bhurtun et al. (2019) describes an excess of nutrients as a result of surface runoff, whereas Lloyd et al. (2016), in contrast, notes a certain stream water "dilution" through rainfall and runoff. Our records of significantly higher discharge and dissolved oxygen, but lower nitrite and $\mathrm{COD}_{\mathrm{KMnO4}}$ levels in Bliznec stream, together with negative correlation between discharge and conductivity indicate that Bliznec displays the "dilution" effect (especially at its headwater site B1), as suggested by LLOYD et al. (2016). We suggest that the natural stream discharge effect additionally depends on the land use/cover (i.e., shading, soil characteristics) and nutrient availability in the ambient areas (LLoyd et al., 2016; ZHANG et al., 2018), as well as on the impact of dissolved oxygen concentration on in-stream nutrient (i.e., nitrite, nitrate) and organic matter (i.e., COD) balance (e.g., SÁNChez et al., 2007; Ge et al., 2012). Excessive nutrients, carried by storm water runoff, can result in increasing biochemical oxygen demand (Francis \& CHADwick, 2013), which is partially confirmed by our COD (i.e., chemical oxygen demand) results.

\section{Stream reaches and sites}

Water temperature, nitrite and nitrate concentrations showed significant differences between stream reaches. The increasing temperature, following a downstream gradient, reflects the surrounding air temperature and shading circumstances of the stream reaches, as it evidenced for many streams withstanding an increasing urban gradient (i.e., influence) along their channels and riparian zones (LeBlanc et al., 1997; Somers et al., 2013; Sun et al., 2015). In the present pilot study, the upper stream reaches showed significantly lower temperature, because 
the sites (B1 and VP1) are situated in a shaded location within the forested area of Nature Park and closer to the source of these streams, whereas the lower reaches (B2, VP2 and B3, VP3) are located within the open urban terrain. In this case, however, the measuring bias must not be omitted. The study sites were measured in two-day intervals following the same sampling schedule. Thus, the timing of sampling might have additionally affected the observed temperature trends between our streams. The nitrite concentration was higher in the lower-most stream reaches (i.e., at the downstream sites), while the nitrate concentration was greater in the middle reaches/sites. These occurrences might be affected by the composition of the riparian zone, as previous studies report (Mello et al., 2018; Sudduth et al., 2013). As well, the nitrite-nitrate balance can be affected by the effects of discharge and dissolved oxygen concentrations on the nitrificationdenitrification balance (SÁNCHEz et al., 2007), and by the activity of the stream bottom dwelling organisms (various microbial, periphytic and macrozoobenthic taxa). Moreover, the observed water quality trends have likely been additionally affected by the inflow of municipal wastewaters (and other anthropogenic sources), land use, land cover and environmental management approach (LiETz, 1999; Mello et al., 2018; Zhang et al., 2018). These authors suggest that forest cover usually acts as a natural water purification system within headwater reaches, whereas changes in landscape configuration metrics coupled with land cover transitions to agricultural and urban landscapes mostly contribute to water quality degradation (i.e., obvious downstream increase of $\mathrm{COD}_{\mathrm{KMnO}}$, nitrogen and phosphorus compounds) in downstream reaches. Forest cover is already known to improve the water quality in different catchment areas worldwide (WANG et al., 2013; Hamilton, 2008; De Oliveira et al., 2016), and to control and decrease in-stream pollutant concentrations (S. DING et al., 2013). In contrast, impervious surfaces in urban areas have been recognized as efficient conduits for wastewater and accumulated pollutants into the recipient streams, as they prevent rainwater to drain into the purifying matrix of vegetation and wetland soils (LeE et al., 2009; J. Ding et al., 2016).

Within each of our stream reaches (and associated sampling sites), discharge varied significantly over the study period, which was especially pronounced upon the high precipitation events (Fig. 2). The rainfall and surface runoff increased the discharge in streams. As a consequence, a high fluctuation of $\mathrm{COD}_{\mathrm{KMnO} 4}$ and nutrients was observed, as seen in Fig 5. Since the nutrients displayed an immense variation over the study period, likely no significant differences between the study dates were detected. However, the extreme variations of physical and chemical water parameters in urban streams (especially changes in natural stream discharge) may lead to major changes in environmental quality and aquatic life (i.e., species diversity, food-web structure and ecological processes) within these ecosystems (Hasenmueller et al., 2017; Verdonschot \& van den Hoorn, 2010; Firmiano et al., 2017 and references therein). Several physico-chemical parameters including discharge, nitrites, nitrates, orthophosphates, conductivity and $\mathrm{COD}_{\mathrm{KMnO}}$ were highly synchronized between the two streams, among the three stream reaches and among the six sites over time, which was corroborated by relatively high 
proxy for temporal concordance $(\tau>0.60)$ of these parameters. This indicated that environmental conditions (stream water quality) synchronously vary across space and over time along our study streams. Some previous studies (e.g VAsseur \& Yodzis, 2004; RuoKolainen, 2013) explained such synchronicity as a consequence of a positive temporal and spatial autocorrelation concluding that: a) consecutive environmental "observations tend to be more similar to each other than those separated by longer time lags" (evidencing positive temporal autocorrelation); b) "more closely located areas tend to be more similar in their local environmental conditions" than those separated by longer distances (evidencing positive spatial autocorrelation). Considering the fast changing environment within urban streams, and the potential influence of the positive temporal and spatial autocorrelation of the environmental conditions (also observed during the present pilot study), we suggest that regular continuous monitoring employing shorter betweensampling (e.g., bi-weekly) intervals of these ecosystems is required, to avoid any false conclusions, particularly when it comes to the development of potential environmental management approaches within urban zones.

In conclusion, our pilot-findings demonstrate that physico-chemical parameters in urban streams are significantly influenced by the surrounding area (land use and cover) and changes in local weather conditions. An increasing urban gradient (i.e., anthropogenic influence) is likely reflected in the urban stream water quality and water quality fluctuations. Nutrients (nitrites, nitrates, orthophosphates), $\mathrm{COD}_{\mathrm{KMnO4}}$ and conductivity showed significant differences between urban areas and forest covered zones, and display high variations during short-term changes in weather conditions and associated natural stream discharge fluctuations.

\section{ACKNOWLEDGMENTS}

We are very grateful to the management and staff of the Medvednica Nature Park and Ministry of Environment and Energy of the Republic of Croatia for supporting this study and allowing access to the study sites located within the Nature Park. We also thank Cyrus Kohlmetz for English proofreading. This study was done as a part of IAESTE internship that enabled students and authors of this study (N. Haas and M. Werner) to participate in this study. We also thank Erasmus + for the financial support of the student (N. Haas).

Received July 23, 2019

\section{REFERENCES}

APHA, 1985: Standard Methods for the Examination of Water and Wastewater. American Public Health Association, Washington. 1268 pp.

Bhurtun, P., Lesven, L., Ruckebusch, C., Halkett, C., Cornard, J.-P. \& Billon, G., 2019: Understanding the impact of the changes in weather conditions on surface water quality. Science of the Total Environment 652, 289-99.

Chen, J.H. \& Chang, H., 2014: Response of discharge, TSS, and E. coli to rainfall events in urban, suburban, and rural watersheds. Environmental Science: Processes \& Impacts 16, 2313-24.

Coleman II, J.C., Miller, M. C. \& Mink, F. L., 2011: Hydrologic disturbance reduces biological integrity in urban streams. Environmental Monitoring and Assessment 172 (1-4), 663-87.

Davis, J., Minshall, W., Robinson, C. \& Landres, P., 2001: Monitoring wilderness stream ecosystems. Gen. Tech. Rep. RMRS-GTR-70. Ogden, UT: U.S. Department of Agriculture, Forest Service, Rocky Mountain Research Station. 137 pp. 
Deutsches Institut für Normung, 1986: Deutsche Einheitsverfahren Zur Wasser-, Abwasser- Und Schlammuntersuchung. 16th ed. Vol II Verlag Chemie, Weinheim.

Ding, J., Jiang, Y., Liu, Q., Hou, Z., Liao, J., Fu, L. \& Peng, Q., 2016: Influences of the land use pattern on water quality in low-order streams of the Dongjiang River basin, China: a multi-scale analysis. Science of the Total Environment 551-552, 205-16.

Ding, S., Zhang, Y., Liu, B., Kong, W. \& Meng, W., 2013: Effects of riparian land use on water quality and fish communities in the headwater stream of the Taizi River in China. Frontiers of Environmental Science \& Engineering 7, 699-708.

FAHNESTOcK, R. K., 1968: Stream channel characteristics. In: Geomorphology. Encyclopedia of Earth Science. Springer, Berlin, Heidelberg.

Firmiano, K. R., Ligeiro, R., Macedo, D. R., Juen, L., Hughes, R. M. \& Callisto, M., 2017: Mayfly bioindicator thresholds for several anthropogenic disturbances in neotropical savanna streams. Ecological Indicators 74, 276-84.

Fleming, S. W., 2007: Quantifying urbanization-associated changes in terrestrial hydrologic system memory. Acta Geophysica 55, 359-68.

Francis, R. \& Chadwick, M., 2013: Urban ecosystems - understanding the human environment. 1st ed. Routledge, Oxon.

Ge, S., Peng, Y., Wang, S., Lu, C., CaO, X. \& Zhu, Y., 2012: Nitrite accumulation under constant temperature in anoxic denitrification process: the effects of carbon sources and COD/NO$-\mathrm{N}_{3}$. Bioresource Technology 114, 137-43.

Grimm, N. B., Sheibley, R. W., Crenshaw, C. L., Dahm, C. N., Roach, W. J. \& Zeglin, L. H., 2005 : $\mathrm{N}$ retention and transformation in urban streams. Journal of the North American Benthological Society 24, 626-42.

Hamilton, L. S., 2008: Forests and water: a thematic study prepared in the framework of the global forest resources assessment 2005. FAO Forestry Paper 155. Food and Agriculture Organization of the United Nations, Rome.

Hasenmueller, E. A., Criss, R. E., Winston, W. E. \& Shaughnessy, A. R., 2017: Stream hydrology and geochemistry along a rural to urban land use gradient. Applied Geochemistry 83, 136-49.

Konrad, C. P. \& Booth, D. B., 2005: Hydrologic changes in urban streams and their ecological significance. American Fisheries Society Symposium 47, 157-177.

LeBlanc, R. T., Brown, R. D. \& Fitzgibbon, J. E., 1997: Modeling the effects of land use change on the water temperature in unregulated urban streams. Journal of Environmental Management 49, 445-69.

Lee, S.-W., Hwang, S.-J., Lee, S.-B., Hwang, H.-S. \& Sung, H.-C., 2009: Landscape ecological approach to the relationships of land use patterns in watersheds to water quality characteristics. Landscape and Urban Planning 92, 80-89.

Lietz, A. C., 1999: Methodology for estimating nutrient loads discharged from the East Coast canals to Biscayne Bay, Miami-Dade County, Florida. Geological Survey, Tallahassee, Florida.

Lizotte, R. E., Shields, F. D., Knight, S. S., Cooper, C. M., Testa, S. \& Bryant, C. T., 2012: Effects of artificial flooding on water quality of a floodplain backwater. River Research and Applications 28, 1644-57.

Lloyd, C. E. M., Freer, J. E., Johnes, P. J. \& Collins, A. L., 2016: Using hysteresis analysis of highresolution water quality monitoring data, including uncertainty, to infer controls on nutrient and sediment transfer in catchments. Science of The Total Environment 543, 388-404.

Mikulčıć, M., 2017: Struktura i trofičke značajke makrozoobentosa urbanih potoka grada Zagreba. Diploma thesis, University of Zagreb, Faculty of Science, Department of Biology, pp. 57.

Mello, K. D., Valente, R. A., Randhir, T. O., dos Santos, A. C. A. \& Vettorazzi, C. A., 2018: Effects of land use and land cover on water quality of low-order streams in

Olds, H. T., Corsi, S. R., Dila, D. K., Halmo, K. M., Bootsma, M. J. \& McLellan, S. L., 2018: High levels of sewage contamination released from urban areas after storm events: a quantitative survey with sewage specific bacterial indicators. PLOS Medicine 15, e1002614.

de Oliveira, L. M., Maillard, P. \& de Andrade Pinto, É. J., 2016: Modeling the effect of land use/land cover on nitrogen, phosphorous and dissolved oxygen loads in the Velhas River using the concept of exclusive contribution area. Environmental Monitoring and Assessment 188, 333.

Peterson, B. J., Wollheim, W. M., Mulholland, P. J., Webster, J. R., Meyer, J. L., Tank, J. L., Marti, E., Bowden, W. B., Valett, H. M., Hershey, A. E., McDowell, W. H., Dodds, W. K., Hamilton, S. K., Gregory, S., Morrall, D. D., 2001: Control of nitrogen export from watersheds by headwater streams. Science 292, 86-90. 
Price, E. L., Sertić Perić, M., Romero, G. Q. \& Kratina, P., 2019: Land use alters trophic redundancy and resource flow through stream food webs. Journal of Animal Ecology 88, 677-689.

Pyron, M. \& Neumann, K., 2008: Hydrologic alterations in the Wabash River watershed, USA. River Research and Applications 24, 1175-84.

Rörig, L. R., Tundisi, J. G., Schettini, C. A. F., Pereira-Filho, J., Menezes, J. T., Almeida, T. C. M., Urban, S. R., Radetski, C. M., Sperb, R. C., Stramosk, C. A., Macedo, R. S., Castro-Silva, M. A., Perez, J. A. A., 2007: From a water resource to a point pollution source: the daily journey of a coastal urban stream. Brazilian Journal of Biology 67, 297-609.

RuoкоLAinen, L., 2013: Spatio-temporal environmental correlation andpopulation variability in simple metacommunities. PLoS ONE, 8, e72325.

SÁnchez, O., Bernet, N. \& Delgenès, J.-P., 2007: Effect of dissolved oxygen concentration on nitrite accumulation in nitrifying sequencing batch reactor. Water Environment Research 79, 845-50.

SCHALLER, M. F., \& FAN, Y., 2009: River basins as groundwater exporters and importers: Implications for water cycle and climate modeling. Journal of Geophysical Research 114, D04103, doi:10.1029/2008JD010636.

Sertić Perić, M., Miliša, M., Matoničkin Kepčija, R., Primc-Habdija, B. \& Habdija, I., 2011: Seasonal and fine-scale spatial drift patterns in a tufa-depositing barrage hydrosystem. Fundamental and Applied Limnology 178, 131-45.

Somers, K. A., Bernhardt, E. S., Grace, J. B., Hassett, B. A., Sudduth, E. B., Wang, S. \& Urban, D. L., 2013: Streams in the urban heat island: spatial and temporal variability in temperature. Freshwater Science 32, 309-26.

StatSoft, Inc. 2010. STATISTICA (Data Analysis Software System). www. statsoft.com.

Sudduth, E. B., Perakis, S. S. \& Bernhardt, E. S., 2013: Nitrate in watersheds: straight from soils to streams? Journal of Geophysical Research: Biogeosciences 118, 291-302.

Sun, N., Yearsley, J., Voisin, N. \& Lettenmaier, D. P., 2015: A spatially distributed model for the assessment of land use impacts on stream temperature in small urban watersheds. Hydrological Processes 29, 2331-45.

VAsseur, D. A. \& Yodzis, P., 2004: The color of environmental noise. Ecology 85, 1146-1152.

Verdonschot, P. F. M. \& VAN DEN Hoorn, M., 2010: Using discharge dynamics characteristics to predict the effects of climate change on macroinvertebrates in lowland streams. Journal of the North American Benthological Society 29, 1491-1509.

Walsh, C. J., Fletcher, T. D. \& Burns, M. J., 2012: Urban stormwater runoff: a new class of environmental flow problem. PLoS ONE 7 (9).

WANG, R., XU, T., YU, L., ZHU, J. \& LI, X., 2013: Effects of land use types on surface water quality across an anthropogenic disturbance gradient in the upper reach of the Hun River, northeast China. Environmental Monitoring and Assessment 185, 4141-51.

World Population Review, 2018: Zagreb population 2019 (demographics, maps, graphs). 27 December 2018. http://worldpopulationreview.com/world-cities/zagreb-population/.

YANG, L., SMITH, J. A., BAECK, M. L. \& ZHANG, Y., 2016: Flash flooding in small urban watersheds: storm event hydrologic response. Water Resources Research 52, 4571-89.

ZhANG, W., Chen, D. \& LI, H., 2018: Spatio-temporal dynamics of water quality and their linkages with the watershed landscape in highly disturbed headwater watersheds in China. Environmental Science and Pollution Research 25, 35287-300. 


\title{
SAŽETAK
}

\section{Kratkoročni učinci prirodnog protoka na kvalitetu vode duž dva urbana potoka - pilot-istraživanje}

\author{
N. Haas, M. Werner \& M. Sertić Perić
}

Povećanjem broja urbanog stanovništva šire se urbane zone koje time mijenjaju krajolik i prirodno stanje okoliša. Povećanjem stupnja urbanizacije mijenjaju se i gradski vodotoci. Voda u urbanim potocima kemijski se onečišćuje raznim toksičnim tvarima iz antropogenih izvora. U ovom pilot-istraživanju praćeni su kratkoročni učinci prirodnog protoka na kvalitetu vode duž dva urbana potoka Blizneca (B) i Velikog potoka (VP) - koji protječu kroz Zagreb, glavni grad Hrvatske. Oba potoka u svom gornjem toku izviru unutar Parka prirode Medvednica, a njihov srednji i donji tok teče duž rastućeg urbanog gradijenta, kroz središnji dio Zagreba. Tijekom ovog istraživanja, u listopadu 2017., svaki drugi dan tijekom dva tjedna mjereni su sljedeći fizičko-kemijski parametri za vodu: protok, temperatura i koncentracija kisika u vodi, konduktivitet, $\mathrm{pH}$ te kemijska potrošnja kisika $\left(\mathrm{KPK}_{\mathrm{KMnO}}\right)$ i koncentracija hranjivih soli (nitrita, nitrata, ortofosfata) u vodi. Najvarijabilniji parametri tijekom dva tjedna bile su koncentracije hranjivih soli. Bliznec je općenito pokazao značajno više vrijednosti protoka i koncentracija kisika u odnosu na Veliki potok, koji je imao značajno više vrijednosti $\mathrm{KPK}_{\mathrm{KMnO} 4} \mathrm{i}$ koncentracija nitrita. Srednji i donji dijelovi toka oba potoka imali su značajno više temperature te koncentracije nitrita i nitrata u odnosu na gornji tok. Podaci ovog pilot-istraživanja su također ukazali na značajne promjene mjerenih fizikalnokemijskih parametara nakon nevremena (razdoblja povišenog protoka vode). Nadalje, korelacijskom analizom je utvrđeno da konduktivitet značajno ovisi o protoku. Ovo pilot-istraživanje pruža dokaze da su urbani potoci vrlo dinamični ekosustavi koji pokazuju povećanu osjetljivost na promjene u okolišu, kao što su antropogeni utjecaji i lokalni vremenski uvjeti. Stoga predlažemo da se u okviru ekoloških studija i pri upravljanju okolišem unutar urbanih zona uzme u obzir značajna ekološka varijabilnost urbanih vodotoka. 
